\title{
О перспективах гендерных исследований художественного текста
}

\author{
Самсонова А.В., магистрант, \\ Северо-Восточный федеральный университет, \\ 2. Якутск \\ E-mail: sashka3991@mail.ru
}

Научный руководитель к.филол.н., доцент Барашкова С.Н.

Критики гендерных исследований в литературоведении в первую очередь утверждают, что гендер не является столь весомым аспектом в исследовании художественных произведений, как к примеру, исторический или биографический. В данной статье, опираясь на последние гендерные исследования художественных текстов, ставится задача опровергнуть данный тезис. Не стоит недооценивать значение гендера в жизни людей. С середины 20 века феминистские волны породили движение гендерных проблем в самых разных направлениях: политология, социология, философия, культурология и многие другие науки заинтересовались концепцией гендера. На данный момент существует огромное множество работ, посвященных гендерной поэтике. Однако, как зарубежные, так и отечественные исследователи до сих пор не разработали четкую методологию гендерных исследований в литературоведении, соответственно нет и методики гендерного анализа текста [4], что позволяет нам говорить об актуальности гендерных исследований.

Общее определение гендера звучит как - социально-культурный феномен, который конструируется в обществе и способен меняться в соответствии с изменениями, как общества, так и культуры. Гендерные исследования - это междисциплинарные исследования, целью которых является разработка стратегий теоретического и практического анализа существующих в культуре представлений о мужественности и женственности, роли в обществе мужчин и женщин, принципов, способствующих и препятствующих достижению гендерного равенства. Становление гендерных исследований как социально-гуманитарной науки началось с 1980-х годов, однако, до сих пор нет устойчивого понятийного аппарата, многие концептуальные подходы все еще находятся в стадии разработки [9].

Важно понять, что не следует отождествлять гендерные исследования с феминистскими. Объект обсуждения феминистских исследований - «критика патриархата как основа культуры, структурно укрепляющего мужское доминирование». Философия феминизма - изучение положения женщины, борьба против дискриминации женщин. Объект гендерных исследований гораздо более шире здесь изучаются как мужские, так и женские проблемы в различных социокультурных, расовых, возрастных группах [7].

В современном литературоведении гендерный аспект занимает значительное место. Как уже упоминалось выше в конце 20 века после феминистских движений, возник интерес к литературе с точки зрения гендера. Гендерные исследования позволяют нам переосмыслить произведения художественной литературы, где четко воплощаются мужской и женский взгляд на мир, на отношения между мужчиной и женщиной. Так на примере наших предыдущих исследований мы может увидеть, что Х.Филдинг в романе «Дневник Бриджет Джонс» и Д. Бримсон в романе «Кое-что о 
Билли» представляют нам жизни двух близких героев, но, в то же время, разных не только в отношении биологического пола, но и гендерного. Эти два персонажа сталкиваются с одной проблемой, это одиночество; и перед ними стоит одна задача найти свою вторую половину. Однако, у каждого из них свои способы достижения поставленной цели, соответственно их гендерному мышлению и положению [8].

В связи с гендерными исследованиями в литературе, появляется направление, которое получает название «гендерная поэтика». Охотникова С.Р. дает следующее определение гендерной поэтики - «это часть исторической поэтики, разработка которой стоит в ряду первостепенных задач современной науки о литературе» [6]. Предметом гендерной поэтики Охотникова С.Р. называет гендер, как «совокупность социальных репрезентаций, «культурная маска пола» в границах тех или иных социокультурных представлений, закрепившихся в данном обществе. В соответствии с данным подходом гендер рассматривается как важный концепт литературы и предстает как измерение социальных моделей поведения, укорененных в данном типе культуры». В свою очередь объектом гендерной поэтики являются «зафиксированные в литературе социально-психологические стереотипы феминности и маскулинности, которые воплощаются в особой картине мира, особой точке зрения автора и героя, особой системе персонажей, в особом характере авторского сознания, объектно-субъектной системе» [6].

Золотухина О.Б считает, что традиционные представления о мужчине и женщине формируют «индивидуальную картину мира и психологию», что приводит к рассмотрению следующих факторов в исследовании гендерной поэтики:

- Проблемно-тематическую специфику

•Систему персонажей (модели поведения, внутренний мир, психологию; типологию);

- Сюжетно - композиционную организацию;

- Речь (дискурсы героев-мужчин и героинь-женщин);

- Конфликт;

- Субъектную организацию (прежде всего, планы точек зрения и повествовательных инстанций (автора, повествователя, героя);

- Хронотоп;

- Стилистику;

- Авторскую картину мира,

- Характер сознания»

Таким образом, художественные произведения будут анализироваться в категориях традиционной поэтики литературоведения, но с проекцией на гендерные аспекты содержания каждой из категорий [2].

Следующий аспект гендерной поэтики - гендерное самосознание. Как всем известно у истоков литературы стоят мужчины, соответственно, художественный мир, который они создавали в своих произведениях, был исключительно мужским: мужчина занимал главную роль, будь он политиком, оратором, путешественником, исследователем, воином и т.п. Основные его характеристики - это ум, сила, отважность, смелость, храбрость, предприимчивость. Женщина в этом мире играла второстепенную роль. Данная модель прослеживается в античности, в средневековых романах, и в романах Просвещения. В качестве доказательства данного утверждения, рассмотрим «Илиаду» Гомера, где Гомер изображает Ахиллеса как «благородного», «любимца богов», «быстроногого», и не смотря на его необузданный гнев, жажду 
мести, вспыльчивость, Ахиллес предстает, перед читателями эпическим идеалом воинагероя. В романе Кристы Вольф «Кассандра» все вышеописанные качества эпического героя для женщины-автора предстают как ужасные, присущие дикому животному: «На лице Ахилла похоть. Обнаженная, ужасающая мужская похоть... Теперь враг, чудовище, ..отделил голову моего брата от туловища... Убийца, мясник, палач с жутким воем побежал прочь. Ахилл, скот». Главная героиня романа не видит в этом «герое» положительных черт: «Сам Ахилл и греки уверяют, будто он сын богини. ... Жрецам это представляется сомнительным. Немало оружия и вина роздал Ахилл ради распространения этой легенды. Тех, кто осмеливается в ней усомниться, ждут самые жестокие кары, а каждый знает: Ахилл умеет покарать, как никто другой». [1].

В. В. Макаров утверждает, что гендерное самосознание - это система, в которой выступают «представления о собственном соответствии моделям феминности и маскулинности, оценка подобного соответствия и готовность поступать в плане создания собственной модели поведения». Гендерное самосознание определяет совокупность принципов литературного творчества в их теоретическом и практическом художественном освоении мира [4]. В гендерном самосознании отражаются историческое содержание эпох, идеологические потребности и представления, отношения литературы и действительности.

По мере «осознания женщины как личности» совершаются попытки проникнуть в женскую психологию и воссоздать ее. Так древнегреческий драматург Еврипид один из первых исследует психологические проблемы, а также раскрывает психологию женщин. В произведении «Ипполит» Еврипид большое внимание уделяет вопросам семьи, персонажи Эврипида размышляют о смысле брака, особенно ярко критикуется «система греческого брака со стороны женщин». В своей трагедии Еврипид создает сложную драму Фреды, показывая глубину и неоднозначность ее чувств. Чуть позже римский философ, поэт Сенека решает интерпретировать данный миф, где изображает мстительную ярость отвергнутой женщины [5]. В современной интерпретации мифа М. Цветаевой, трагедия Фреды - это драма о трагичной любви. М. Цветаева освобождает Федру от вины, так как не видит вины в любви [3].

Следовательно, на данном примере мы можем увидеть различные интерпретации мифа с точки зрения мужчин и женщин.

Таким образом гендерное литературоведение является одним из наиболее перспективных направлений науки. Гендерное литературоведение позволяет интерпретировать многие произведения с иной стороны, и открывать новые завесы тайн художественных произведений.

\section{Список литературы}

1. Вольф К. «Кассандра» / К. Вольф // [Электронный ресурс] - Режим доступа: http://royallib.com/book/volf_krista/kassandra.html - Дата обращения: 28.02.2017

2. Золотухина О.Б. Психологизм в литературе / О.Б. Золотухина // [Электронный pecypc] - Режим доступа: http://ebooks.grsu.by/psihologism_lit/3-gendernyeissledovaniya.htm - Дата обращения: 03.02. 2017

3. Крючков В.П. Поэтическая драма "Федра" / В.П. Крючков // [Электронный pecypc] - Режим доступа: razbor_poeticheskih_proizvedenii_russkie_i_zarubezhnye_poety/66russkaya_poeziya_xx_veka_ocherki_poetiki_analiz_tekstov/stages/3077poeticheskaya_drama_fedra.html - Дата обращения: 03.03.2017. 
4. Макаров В.В. Основные принципы философии пола: Ст. первая. Биологический диморфизм, гендерная симметрия // Женщина в российском обществе. 2001. №2. С. 17.

5. Макаров Д. Примеряя трагическую маску Федры / Д. Макаров // [Электронный peсурс] - Режим доступа: http://www.ijp.ru/razd/pr.php?failp=12000601448 - Дата обращения: 04. 03. 2017.

6. Охотникова С.Р. Гендерные исследования в литературоведении: проблемы гендерной поэтики / С. Р. Охотникова // [Электронный ресурс] - Режим доступа: http://www.a-z.ru/women_cd1/html/gender_issledovanija_v_literature.htm. - - Дата обращения: 02.02.16

7. Пушкарь Г.А. Типология и поэтика женской прозы. Гендерный аспект [Электронный pecypc] - Режим доступа: http://www.twirpx.com/file/707089/- Дата обращения: 11.10.16.

8. Самсонова А.В. Гендерная проблематика английской прозы на примере романов Филдинг Хелен «Дневник Бриджет Джонс» и Дуги Бримсон «Кое-что о Билли» / А.В. Самсонова, С.Н. Барашкова // [Электронный ресурс] - Режим доступа: http:/nti.s-vfu.ru/downloads/doc/XVII\%20конференция\%20том\%202\%20Секции\%2047.pdf - Дата обращения: 27.02.2017.

9. Хеффе О., Малахова В.С. Современная западная философия. Энциклопедический словарь / Под. ред. О. Хеффе, В.С. Малахова, В.П. Филатова, при участии Т.А. Дмитриева. М., 2009, с. 12-14. - [Электронный ресурс] - Режим доступа: http://ponjatija.ru/node/11223 - Дата обращения: 02.02.2017

\section{Концепт «мистика» в повести Н.В. Гоголя «Вий»}

Седина Д.Р., студентка, Технический институт (филиал) Северо-Восточного федерального университета, 2. Нерюнгри E-mail: nieftisova@mail.ru

Научный руководитель: к.ф.н., доцент Яковлева Л.А.

Целью данной статьи является рассмотрение структуры концепта «мистика» на примере произведения Н.В. Гоголя «Вий».

Актуальность работы обусловлена тем, что изучение художественной картины мира писателя является неисчерпаемым средством познания и осмысления как картины мира, так и творческой позиции личности.

Прежде чем приступить к исследованию концепта мистика в творчестве Н.В. Гоголя, необходимо ознакомится с взятым за основу алгоритмом концептуального анализа художественного текста, предложенным Л.Г. Бабенко, Ю.В. Казариным:

1) Выделение предтекстовых пресуппозиций, важных для формирования концептуального пространства текста.

2) Анализ семантики заглавия и его семантического радиуса.

3) Проведение психолингвистического эксперимента с целью выявления набора ключевых слов текста. 